DOI 10.37882/2223-2982.2021.11.10

\title{
ИСПОЛЬЗОВАНИЯ ХОЗЯЙСТВЕННОГО РАСЧЕТА В КУЛЬТУРНЫХ ОБЪЕКТАХ ПЕНЗЕНСКОЙ И УЛЬЯНОВСКОЙ ОБЛАСТЕЙ
}

\section{THE USE OF ECONOMIC CALCULATION IN CULTURAL OBJECTS OF THE PENZA AND ULYANOVSK REGIONS}

\section{O. Golubeva}

Summary: This article discusses the implementation of the introduced program of economic development in the cultural sphere of the Soviet Union in the mid-80s of the XX century. The article is based on the use of state archival data, which presents reports on the use of economic calculation in cultural objects of the Penza and Ulyanovsk regions, organized by employees of club institutions during the activities of the Councils of People's Deputies. Thus, the leadership of the party organizations ensured the active participation of the introduction of selffinancing among workers of the spiritual sphere.

Keywords: the idea of "decentralization of economic management, introduction of economic calculation, improvement of the infrastructure of a cultural institution, economic management system, employee interest, restructuring, self-financing, self-sufficiency, self-government.
Л юбая модель развития государства предполагает неразрывную связь со всеми сферами жизни людей в обществе и отраслями ее производства, поэтому каждое экономическое изменение в обществе поддакивало правящие круги к переменам не только в экономической и политической, но и социальной, и духовной сферах.

«Выступая на Всесоюзном совещании по проблемам научно - технического прогресса, состоявшемся 11-12 июня 1985 года, Горбачев М.С. говорил о своей приверженности делу Ленина, верности социалистическим идеалам, отмечая успехи в развитии страны... Генеральный секретарь провозгласил концепцию хозяйственного механизма, включавшую форсирование научно - технического прогресса, реконструкцию отечественного машиностроения, производство новых машин и оборудования, применение высоких технологий» [5. с. 28.].

Наряду с этим выдвигалась идея «децентрализации управления экономикой, расширения прав предприятий, внедрения хозяйственного расчета. Повышения ответственности и заинтересованности трудовых коллективах» [4, с.280.].
Голубева Ольга Николаевна

Аспирант, Самарский национальный исследовательский университет им. академика С.П. Королева

golubewaolga1969@mail.ru

Аннотация: В данной статье рассмотрено проведение вводимых программы экономического развития в культурной сфере Советского Союза в середине 80 годов XX века. Статья составлена на основе использования государственных архивных данных, где представлены отчеты использования хозяйственного расчета в культурных объектах Пензенской и Ульяновской областях, организованные работниками клубных учреждений при деятельности Советов народных депутатов. Таким образом, руководством партийных организаций обеспечивали активное участие введение хозрасчета в среде работников духовной сферы.

Ключевые слова: идея «децентрализации управления экономикой, внедрения хозяйственного расчета, улучшение инфраструктуры культурного учреждения, система экономического хозяйствования, заинтересованность работников, перестройка, самофинансирование, самоокупаемость, самоуправление.

Данные меры были необходимы в экономике. Они способствовали повышению роли управления центрального звена государства и «стабилизации финансов в оздоровлении потребительского рынка» [6. с.196].

Вводимый на предприятиях хозяйственный расчет включал в себя три компонента: самофинансирование, самоокупаемость, самоуправление.

«Согласно новой концепции между предприятиями, должна была возникнуть конкуренция, заступающая на место прежнего социалистического соревнования. Ценообразование должно было определяться механизмами рынка, рыночная среда выступала в качестве регулятора рентабельности, прибыли, заработанной платы. Предприятиям предстояло самим заботится о закупках, сбыте продукции, об инвестициях» [7, с.37.].

Таким образом, экономическое нововведение было принято и другими сферы общественного развития. Данные меры - расширения прав предприятий, внедрения хозяйственного расчета, отмечаются в решениях Советов народных депутатов Ульяновской и Пензенской областей, где комиссии по культуре предлагают использование хозяйственного расчета в составлении плани- 
рования на определенный период рабочего времени.

Первые отклики нововведения наметились в Пензенской области, где в работе учреждений культуры все больше внедряются хозрасчетные начала.

Но, все же, «учреждениями культуры района оказано платных услуг населению на 103 тысячи рублей при плане 62 тысячи рублей» [1, с.3].

Введение программы хозрасчета позволяло работникам культуры (государственных учреждений) пополнять мелкие потребности в развитии своего производства, но все же оставалась планово - экономическая система ведения хозяйства, поэтому большая часть заработанных ими денег уходило на развитие государства и нужды партии.

Но все же, перевести на хозрасчет и систему экономического хозяйствования в области культуры позволили получить следующий результат: «за 1987 год оказали услуг на 28 тыс. рублей, по итогам 1988 года на 42 тыс. рублей. Полученные средства идут на улучшение инфраструктуры культурного учреждения, театральные костюмы, премирование лучших работников» [1, с.4].

Опыт пензенского районного дома культуры по оказанию платных услуг распространяется и на другие учреждения культуры области: «Засечный ДК заработал 3.1 тыс. руб., Ст. Каменский ДК -4.1 тыс. руб., Алферьевский ДК - 2.4 тыс. рублей, Надеждинский и Мичуринский от 400 до 600 рублей».

В материалах выступления, заседания Совета депутатов Пензенской области, приводится следующий момент рассуждения о действии хозяйственного расчета: «Думается, что такой опыт надо распространять и смелее брать на вооружение. Но это конечно не значит, что все должно быть поставлено на коммерческую основу, и коллектив РДК и названные клубные учреждения должны расширять сеть творческих объединений, особенно для школьников и рабочей молодежи» $[1$, с.5].

Хозяйственный расчет предполагал применение инициативы и творчества в развитии деятельности дома культуры. Но будучи зависимым от решения вышестоящей власти, нельзя в тот период времени, менять свою программу развития - проведения мероприятий, они оставались прежними, а именно: «Смотр - конкурс вокально-хоровых коллективов», «Пою, мое Отечество!». Смотр конкурс «Играй, гармонь», районные праздники, посвященные Дню советской молодежи и 70 - летию ВЛКСМ, традиционный тематический вечер «Встреча допризывной молодежи с воинами - интернационалистами и ветеранами Великой Отечественной войны» [1, с.5].
Заинтересованность работников результатами своего труда, в любой отрасли производства, проходила через проведение социалистических соревнований. Если на производствах сравнивались показатели в изготовлении и продажи продукций, то в культурной отрасли подводились итоги среди проведенных мероприятий и их численности посещений. «При подведении итогов в социалистических соревнованиях работников культуры за 1988 год среди сельских домов культуры, были вручены Почетные грамоты и переходящий вымпел отдела культуры и РК профсоюзов работников культуры» [1, с.6].

Ульяновский городской совет народных депутатов рассматривал решение хозяйственного расчета в следующем формате: переписка с Главлитом СССР по вопросам основной деятельности от 14 января 1989 г.

Итак, в материалах отмечается:

- Использование принципов хозяйственного расчета в деятельности органов Главлита СССР и перехода к финансированию части выполняемых ими работ по специальному редактированию (предварительный контроль) материалов газет, журналов, издательств, телевидения, радиовещания, информационных агентств, кино, министерств и ведомств, и других организаций.

- Целью введения принципов хозрасчетного расчета является повышение эффективности и оперативности предварительного контроля материалов на основе совершенствования форм оплаты труда работников по оконечным результатами и сокращения затрат бюджетного финансирования.

- Основой хозрасчетной деятельности для производственно - редакторских организаций являются доходы, полученные от редакции газет, журналов, издательств, телевидения, радиовещания, информационных агентств, киностудий, министерств и ведомств, других предприятий и организаций, материалы которых проходят предварительный контроль.

Указанные доходы используются на содержание оплаты труда, фонда производственного и социального развития и централизованного фонда Главлита СССР.

- Из доходов, полученных за выполняемую работу, производится отчисления средств в централизованные фонды и резервы Главлита СССР и Главлитом союзных республик по установленным нормативам. Отчисления Главлиту СССР управлениями РСФСР и главлитами союзных республик производится непосредственно. А управлениями союзных республик - через соответствующие республиканские главные управления [2, с. 4 - 7].

Таким образом, все звенья в советской культуре были подвержены новым хозяйственным изменениям, а цен- 
тральным связывающим звеном в цепи до 1991 года оставалась КПСС, так как партия выполняла часть основных функций в деятельности Главного управления по делам литературы и издательств.

Управление по охране государственных тайн в печати при Ульяновском облисполкоме (обллит) информирует совет народных депутатов о том, что «организовали оперативный переход обллита на хозяйственный расчет. Кроме того, введение хозрасчета позволило обллиту делать значительные приобретения. Приводится приме в покупке цветного телевизора стоимостью 742 рубля. И отмечаются небольшие накопления на счете в банке свыше 4000 рублей» [2, с. 45 - 46].

Перестройка и новые веяния государственных преобразований позволили переосмыслить происходящие жизненные и общественные моменты небольшой области, поэтому на обсуждение Ульяновского городского совета народных депутатов был вынесен вопрос о создании центра социально - культурного развития города, работа которого предполагалась строиться на хозрасчетных началах, на обсуждение комиссии Совета народных депутатов было вынесено выступление представителей научно - исследовательского центра «Город»:

«Этот центр, состоящий из лабораторий социального анализа, лаборатории вычислительной техники и редакции городского газеты, должен действовать на принципах самостоятельности (т.е. независимости от «аппарата») и хозрасчета (с частичным бюджетным финансированием, поскольку издание газеты дело капиталовиков).

Предполагается, что единый информационно - социологический центр, позволит обеспечить прохождение информации по следующей схеме:

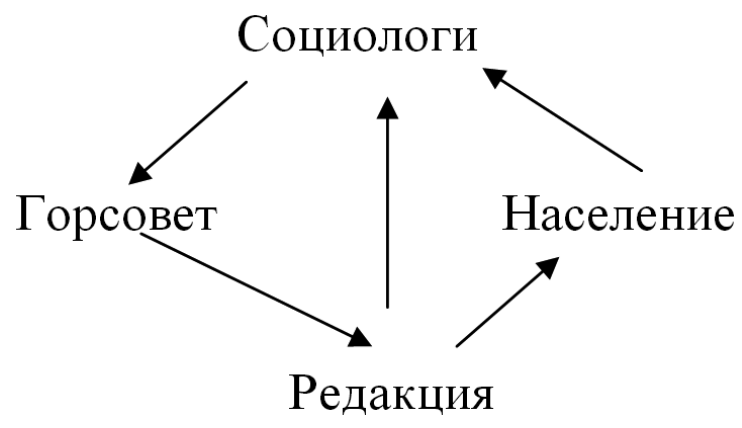

Таким образом, редакция будет информировать население города о работе Совета, его президиума, комиссий и исполкома. А социологи, проведя опросы общественного мнения будут разрабатывать рекомендации и предложения по «корректировке» и совершенствованию работы совета [2, с. 15].

По мнению специалистов, такой подход к решение данного вопроса считается наиболее конструктивным и рациональным. Создание информационно - социологического центра предполагал перестроить систему управления на основе постоянного учета общественного мнения населения, отойти от умозрительных решений к научно обоснованным программам и проектам развития города. Данный центр предложено было организовать при помощи работы социологов и журналистов, а руководителем намеченным центром должен быть президиум Горсовета. Одним из основных рассматриваемых вопросов данного центра - «...принимать участие в исследованиях по проблемам теневой экономики».

Предложение было встречено бурными обсуждениями. Материалы постоянной комиссии по науке, народному образованию, культуре сохранили сведения о рассуждениях членов комиссии. Итак, Ступников Г.И.: «В городе дефицит журналистов и социологов, центр будет добиваться взаимосвязи депутатов и избирателей. Сейчас Горсовету нужна информация и центр будет мобильной структурой, а уж как мы воспользуемся этой информацией, будет зависеть от нас - депутатов».

Шувалова В.С. отметила, что перспектива- служба для оперативного сбора информации над одной темой работы идет несколько лет. Организация должна быть хозрасчетной, работать по нескольким договорам, центр должен быть маленьким нашей группой уже подготовлены материалы: социальное положение женщины, организация культурного досуга, семья и школа. Любые исследования обходятся в сумму 35 тыс. рублей. Если горсовет хочет создать такой центр, то это появление монополии, этого не должно быть.

Скворцов В.Н. заметил, что «в нашей лаборатории есть уже наработки по социальной карте города, по самоуправлению. Депутаты должны предусмотреть деньги в бюджете на изучение опроса населения по тарифным нормам».

К.С. Овсянников предлагал: - «Служба нужна, депутаты должны владеть информацией, но служба должна быть мобильной. Надо предусмотреть целевое финансирование, закупить компьютеры горисполкомом, и никак газету нельзя отождествлять вместе, газета должна быть также самостоятельным органом.

Решение комиссии на тот период времени, можно считать однозначным: создание центра преждевременно, необходимо создать мобильную экспертную группу, создание центра может привести к монополизации» $[2$, c. 16].

Партийное руководство области не могли в середине 80 -х годах XX века позволить выделить средства на дополнительные исследования жизни населения области. 
Так инициатива группы совета народных депутатов не была реализована.

Вводимый хозяйственный расчет в культуре и ее смежных отраслях по данным Пензенского Государственного архива не помог повысить уровень жизни работников культуры, «если сравнивать со средней ежемесячной заработанной платой 1988 года, то на данный период времени она исчислялась для клубного работника суммой в 100 рублей». Сведения заседаний Совета народных депутатов Пензенской области содержат следующие: «Итак, работники культуры принижены в материальном плане. Это одна из самых низких зарплат из всех категорий, работающих в районе. Обделенная социальными правами - жильем, яслями. Может быть, райисполком и райком партии возьмутся в серьез за дело контроля собственных решений. Пора, наверное, перейти от остаточного принципа финансирования культуры, если мы хотим, чтобы культура была действительно культурной» [1, с.7].

Ульяновский городской совет народных депутатов, ее постоянная комиссия по науке, народному образованию, культуре отмечает в одном из обращении на недочеты данного производства в виде - «нет книжных из- дательств, научно - исследовательских организаций, а есть только три издающие организации - пединтститут, сельскохозяйственный и политихнический, которые погоды не делают» $[2$, с.46].

Таким образом, хозрасчет, вводимый на предприятиях, буксовал из-за отсутствия рыночных механизмов [6, c. 187].

Происходящая в стране перестройка невозможна без возрождения важнейших ценностей социализма, использование новых методов хозяйствования [3, с.11].

Хозяйственный расчет должен был обеспечить свободное и всестороннее экономическое развитие человека не только в культурной, но и в других сферах деятельности общества.

Сегодня, когда активно обсуждается вопрос, что надо сделать, чтобы преодолеть препятствие, стоящие на пути перестройки, дать новый мощный импульс революционному процессу обновления, когда ведется активный поиск стратегических направлений совершенствования нашего общества, неотложной задачей стала реорганизация политической системы [3, с.11].

1. Государственный архив Пензенской области. Ф.Р 2656, 0.1, д.109.

2. Государственный архив Ульяновской области. Ф. Р- 634, 0.2, д. 1594.

3. Батурин Ю.М. Перестройка: гласность, демократия, социализм. Реформы. Юристы и политологи размышляют/Батурин Ю.М. Издательство: М. Прогресс. 1989, C. 349.

4. Горбачев М.С. Жизнь и реформы. Кн.1. С. 280

5. Пихоя Р.Г. Москва. Кремль. Власть. Две истории одной страны. Россия на изломе тысячелетий. 1985 -2005/ Рудольф Пихоя. - М.: Русь - Олимп: Астрель: ACT, 2007. - 554 C.

6. Пихоя Р.Г., Соколов А.К. История современной России: кризис коммунистической власти в СССР и рождение новой России. Конец 1970-х - 1991 гг. / Р.Г. Пихоя, А.К. Соколов. - М.: Российская политическая энциклопедия (РОССПЭН); Фонд Первого Президента России Б.Н. Ельцина, 2008. — 423 с.

7. Согрин. В.В. Политическая история современной России. 1985 - 2001: от Горбачева до Путина/ Серия «Высшее образование». - М. Издательство «Весь мир», $2001-272$ c.

() Голубева Ольга Николаевна (golubewaolga1969@mail.ru).

Журнал «Современная наука: актуальные проблемы теории и практики» 